\title{
VERSENYKÉPESSÉG
}

\section{A VÁROSHÁLÓZAT AZ ÁTMENETBEN, A KILENCVENES ÉVEK VÁLTOZÁSI IRÁNYAI}

(The Hungarian Urban System in the Transition, Changing Direction in the 90s)

\author{
RECHNITZER JÁNOS
}

\begin{abstract}
Kulcsszavak:
városhálózat nagyváros kisváros városifunkciók

Az átmenet területi folyamatainak vizsgálatakor nem feledkezhetünk meg a városhálózat szerkezeti elemzéséröl. A városok a megújitás hordozói, azok funkcióinak változása, illetve az alkalmazkodási képességük alapvetőn befolyásolja a térszerkezet alakulását. A modernizációs elemek, a piacgazdaság intézményei a városokban telepednek meg, hiszen követniük kell a hierarchikus terjedés szabályait, s a különbözö adottságokkal rendelkezö centrumok hálózatán, annak egybekapcsolódása révén hatolnak aztán a tér további pontjaiba, szövik át a területrendszert.
\end{abstract}

Elemzésünkben arra vállalkoztunk, hogy egy korábban végzett (1989-1990-es bázison), az akkori városhálózatra vonatkozó vizsgálatunkat a kilencvenes évek utolsó harmadában megismételjük (1997-1998). A két vizsgált időpont között természetesen jelentősen nőtt a városok száma. A változók egy részét már nem lehetett számba venni, illetve újabb jelenségek bukkantak fel, amelyek nélkül viszont nem volt érdemes a hálózatot vizsgálni. A két elemzés tehát több ponton kapcsolódik egymáshoz, de éppen a megfigyelési egységek és azok jellemzőinek különbözőségei miatt el is tér az első a másodiktól.

Arra a kérdésre viszont, hogy mi jellemezte a városhálózatot az átmenet kezdetekor és a kilencvenes évek végén, azaz történt-e elmozdulás a szerkezetben, és ezt milyen tényezők mozgatták, megítélésünk szerint választ tudunk adni. Az összehasonlítás tehát elvezet a hálózat jellemzőinek, az összetartozását meghatározó elemeknek és azok tagozódásának, a közös rendszerelemek alapján szerveződő csoportok meghatározásához, s ezzel talán a városhálózat jövőbeli trendjeinek felvillantásához.

\section{Városhálózat jellemzői a kilencvenes évek elején}

Elemzésünkben elsőként egy helyzet-, mondhatni indulóképet vázolunk fel, alapvetően a nyolcvanas évek végén (az 1988-1990-es évek adatai alapján) regisztrálható állapotokat (Rechnitzer 1993, 113-124). Az indulás évei ezek, ekkor jelennek meg a piacgazdaság intézményei, hol tömegesen, hol egyedileg, ekkor kezdődik el 
az adaptálásuk. Ebből következik, hogy egy innováció-hordozó elemkombinációt gyüjtöttünk, gyüjthettünk össze. Azt a kombinációt, amely vélhetően jelzi, kifejezi a centrum települések reagálását a kibontakozó piacgazdaságra. Módszertani bázisunk a faktor-és klaszteranalízis volt, amelynek hibái ismertek, azonban képes mégis kezelni a nagy tömegű változókat és megfigyelési egységeket.

A városhálózatnak a rendszerváltozás évében 165 egysége volt, ami megfelelő tömeg a törvényszerüségek kimutatására. A változókból a következő, döntően a megújítást képviselő csoportokat alakítottuk ki:

- A gazdasági-szervezeti aktivitás alatt a vállalkozás-aktivitás mértékét és jellegét (hazai és/vagy külföldi érdekeltségü társas vállalkozások elterjedése), az előprivatizációba bevont egységek nagyságát, illetve a lakosság jövedelmi-megtakarítási és fogyasztási szintjére vonatkozó információkat tüntettük fel.

- A termék és tevékenység innováció alatt szerepeltettük a telefon, a telefax és a CB ellátottságot, az egyes városok számítógép-kapacitásának nagyságát, de ide soroljuk a gépkocsik és a lakosság külföldi utazási hajlandóságát kifejező világútlevelek számát is.

- A szellemi erőforrások között jelenítettük meg a lakosság iskolai végzettség szerinti megoszlását ${ }^{1}$, a középfokú intézményekben tanulók számát, és a különböző oktatási szinteken nyugati nyelveket tanulók arányát.

- A társadalmi-politikai innovációk jelenlétének kimutatásához figyelembe vettük a különböző jellegű napi- és hetilapok előfizetőinek a számát, az utolsó országgyülési képviselő-választáson résztvevők arányát, valamint a helyivárosi alapítványok számát.

- A centrum funkcióknál és a népességi aktivitásnál tüntettük fel azokat a tényezőket, amelyek a városok ellátottságát és egyben vonzó hatását voltak hivatva megjeleníteni. Így a népesség számának változását, a tényleges szaporodás/fogyás mértékét, az épített lakások számának változását (mindkettőt 1980-1990 között), valamint egy összevont mutatóval az intézményi ellátottságot ${ }^{2}$ soroltuk ebbe a változó blokkba.

A faktoranalízissel végzett elemzéssel megállapítható, hogy a városok innovációs környezetét, s egyben az újdonságok fogadásának jellegét egyrészt a centrumok intézményi ellátottsága, felszereltsége, másrészt pedig a lakosság iskolai végzettsége, és az ahhoz rendkívül szorosan kapcsolódó, vele egy faktorba tömörülö új típusú vállalkozások jelenléte határozza meg.

A centrum funkciók és a népességi aktivitás közül mindegyik számottevően befolyásolta a városok újdonság fogadását. A központok vonzásának erősségére utaló lakásállomány változás, valamint az ehhez is szorosan kapcsolódó tényleges szaporodás/fogyás a determináló tényezői az újdonságok megtelepedésének, ám mindezeken is túltesz az intézményi ellátottság, azaz a városi szerepkörök minél szélesebb megléte.

A kiválasztott gazdasági-szervezeti tényezők szintén alkalmasak a városok innovációs környezetének jellemzésére. A centrum funkciókhoz is kötődő gazdasági 
változók - mint pl. a kereskedelmi forgalom - egyértelmủen az ellátottsághoz, a városi szerepköröket megtestesítő faktorhoz kapcsolódnak. Míg a gazdasági innovációt szemléltető tényezők - mint a vállalkozás-aktivitás más-más megközelítésü elemei-már eggyé tartoznak, szorosan egymáshoz kapcsolódnak, elkülönült faktort hozva létre.

A termék és tevékenység innovációt szimbolizáló elemek közül csak a telefontelefax elöfizetők száma és a személygépkocsi állomány nagysága hozható egyértelmü összefüggésbe az innovációs hajlandósággal. Ebben a változócsomagban szerepeltettük az egyes városok távolságát a fỏvárostól. Egyértelműen kitünt, hogy a földrajzi távolság negatív módon hat a városok innovációs fogadóképességére, vagyis a centrumok minél távolabb vannak Budapesttől, annál kevésbé települtek ott meg újdonság hordozó és közvetítő tényezők. A távolsággal kapcsolatos és a területi kutatásokban evidensnek tartott megállapítást csak azért emeltük ki, hogy ismét rávilágítsunk a föváros kiemelt szerepére, meghatározó jellegére a város- és településhálózatban, illetve annak újdonság fogadásában.

A szellemi erőforrásokban, azokon belül is a közép- és a felsőfokú végzettségüek nagyságában kell keresnünk városaink alapvető és meghatározó innováció-gerjesztő tényezőit. A magasan kvalifikált népesség gazdaságilag aktív, fogékony az újdonságok iránt, döntő szerepe van a vállalkozások terjesztésében, de a városok felszereltségét, intézményekkel való ellátottságát is erőteljesen befolyásolja, meghatározza.

A társadalmi-politikai aktivitás már az előzőkből következik. Hiszen a lakosság intellektuális színvonala szorosan kötődik az újdonságokat közvetítő médiák jelenlétéhez, ám a politikai vagy a közösségi aktivitás e tényezőkkel, egyben az innovációs miliő további meghatározóival már nem került vizsgálatunk alapján kapcsolatba. Azt hisszük ez érthető is, mivel a társadalmi aktivitás formái, szervezetei csak az elemzés éveiben formálódtak ki. Hatásaikat, közvetlen befolyásukat még nem lehet kitapintani a városok innovációs miliőjében, annak alakításában.

A városhálózat innovációs környezetét tehát az általunk kijelölt elemkombináció szerint a kilencvenes évek elején alapvetően és döntően a városok intézményi felszereltsége, a lakosság iskolázottsága, valamint a vállalkozás-aktivitás mértéke határozza meg. Ennek következtében vélhetően a kilencvenes években a jobban felszerelt, jelentősebb polgári hagyományokkal és aktív, erősödő lokális-regionális piaccal rendelkező városokban várható a gyorsabb és zökkenőmentesebb átmenet a piacgazdaságra. E faktorok serkentésével, sokoldalú aktivizálásával ugyanakkor elérhető a városhálózat egyes - de sajnos nem minden elemének - felzárkózása, viszont hiányuk és hatásaik mérsékelt volta esetében a városok további differenciálódása erőteljes lehet.

Vizsgálatunknak nemcsak az volt a célja, hogy kiemeljük a változótömegből az innovációs környezetet legjobban érzékeltető tényezőket, hanem az összetartozó csoportokat, az azonos jellemzőket mutató városokat is meg kívántuk határozni. A klaszteranalízissel többszöri kísérlet után öt osztályba sorolhattuk a megfigyelt centrumokat. 
A kapott eredmény megosztott városhálózatot illusztrál, amelyben felismerhetők a makroregionális különbségek éppen úgy, mint a népességszám szerinti megosztottság is. Ezen utóbbi összeállításból az első benyomásunk az, hogy a tradicionális nagyvárosok és az új vagy történelmi kisvárosok elkülönülnek egymástól.

A mély és széles szakadékot csak a középvárosok egy kisebb hányada próbálja meg áthidalni a Dél-Alföldön, az Észak- és Nyugat-Dunántúlon, elszórva ÉszakMagyarországon, de a korábbi történelmi városok közül sokan leszakadtak, a kisvárosi csoporthoz sodródtak (Észak-Alföld). Észak-Dunántúl városhálózata az elemzések alapján tehát sokszínűbb, az innovációs környezet minőségében eltérő. Vélhetően ezen városhálózatban az újdonság hordozó tényezők alapján hierarchia formálódik ki, amely a térszerkezetre is pozitív hatással lesz. Éles ellentét tapasztalható a föváros agglomerációjában, hiszen a városok egy nyugati és egy keleti övezetre tagozódnak.

A Dél-Dunántúlon a két nagyváros alkot innovációs szigetet, hasonlóan a Alföldhöz, ahol szintén a tradicionális, regionális funkciókkal rendelkező nagyközpontok látványosan emelkednek ki a városok teréből, de a Dél-Alföldön KecskemétSzeged vonulatában felismerhető már egy azonos megújítási jegyeket mutató városhalmaz is (Kiskőrös - Kiskunfélegyháza - Csongrád - Szentes - Hódmezővásárhely - Makó).

Észak-Magyarország városhálózata igencsak megosztott, töredezett. Csak egy aktívnak ítélhető centrum bukkan fel, és néhány, az újdonságok fogadását megkezdő, a korábbi gazdasági bázis átalakításával nehezen küszködő adaptációs központ. Kiugrik tehát már első pillantásra is az innovációs környezet által megosztott városhálózat, amelyet a korábbi fejlődés eredményei, ám egyben felhalmozott feszültségei és az elmúlt esztendők megújítási nekirugaszkodásainak együttes hatása formált, alakított ki.

Tekintsük át és értelmezzük az egybetartozó, az azonos innovációs környezeti jegyeket mutató csoportokat.

\section{A potenciális innovációs központok, a megújitások aktiv és sokoldalú környezete}

A magas újdonság hordozók számában, a vállalkozás-aktivitás kiugró értékeiben, a szellemi erőforrások jelentős koncentrációjában, végezetül a városok közel azonos, de az egész hálózathoz mérten is kiemelkedő színvonalú ellátottságában találjuk meg a csoportképzés ismérveit. Feltételezhető, hogy fokozatosan kapcsolatba kerülnek az innováció-hordozó tényezők egymással, így megindulhatnak az egymásra hatások, néhány tényezőcsoportban érvényesülhetnek a szinerg effektusok. Adottságaik, mint kiemelkedő endogén jellemzőik lehetőséget kínálnak - ezért ragasztottuk e csoporthoz a potenciális jelzőt - újabb és újabb innovációs elemek megjelenéséhez, illetve azok városon belüli és térségi terjedéséhez. A csoportot 14 város alkotja, ebböl hét (Győr, Székesfehérvár, Pécs, Kecskemét, Szeged, Debrecen, Nyíregyháza) a tradicionális nagyváros, valamint a Dunántúlról még öt megyeszékhely; Szombathely, Zalaegerszeg, Kaposvár, Veszprém, Tatabánya, az Alföldről ugyancsak megyeközpontként Békéscsaba és végül Észak-Magyarországról 
csupán Salgótarján. Vélhetően a korábbi - talán egyoldalú és sokat bírált - megyeközpont fejlesztés eredményeként kialakult az országban egy aktív, az innovációk fogadására képes és alkalmas (nagy)városi hálózat, amely fontos szerepet kaphat az egész ország gazdasági, politikai és társadalmi átalakulásában.

\section{A speciális innovációs központok, kommunikáció és vállalkozás orientált megúji-} tási környezet

Az előző csoporttól elkülönült 8 várost a kommunikációs tényezők (személygépkocsi, telefon-telefax-ellátottság) és a vállalkozás-aktivitási mutatók közül a vegyesvállalati megtelepedést kifejezö paraméterek kötik össze, amelyhez társulnak még a lakosság iskolázottságára vonatkozó tényezők mint klaszterképzők. Mindezek mellett kiugróak az alapellátottságot reprezentáló endogén változók értékei, de több innováció-hordozó tényező jelenléte is kimutatható, ám ezek összekapcsolódása még nem indulhatott meg. A Dunántúlon található mind a nyolc központ, ebből három a fóváros nyugati agglomerációjának centruma - Szentendre, Érd, Budaőrs , ahol a külföldi és a hazai vállalkozások megtelepedése rendkívül intenzív, de ezeket a központokat preferálják a Budapestről kitelepülő magasabb jövedelmü és iskolázottságú rétegek is. A Balaton mellett Balatonalmádi, Balatonfüred és Siófok számottevő újdonság hordozó tényezőt koncentrál, de a városok idegenforgalomra épülő, éppen ezért megújításra érzékeny gazdasági bázisa - amelyhez párosul magasabb felszereltsége - sajátos, elkülönült innovációs miliőt eredményez. Ugyanezt mondhatjuk el Sopronról és Köszegröl is, talán annyival többet, hogy az országhatár megnyitása, az Ausztriához való közelség számos újdonság megtelepedését eredményezte. Mindezek együttesen alapvetően átformálják a városok gazdasági, társadalmi, szerkezeti, de kapcsolati rendszerét is.

\section{A készülök és a felzárkózók, az adaptáció orientált környezet}

Az e csoportba sorolódott városoknál megtelepedtek már az egyes innovációhordozó elemek, ám közöttük a kapcsolatok lazák, az érzékelhető egybetartozás még nem mutatható ki, azaz az újdonságok az adaptációs fázisban vannak. Hiszen gazdasági felszereltségük, intézményi ellátottságuk és társadalmi adottságaik kedvező feltételeket biztosíthatnak egy vagy több további innovációs tényező megtelepedésére, valamint a centrumok és térségük aktivizálódásának megindulásához.

A csoport nem homogén, így tagjait korábbi funkciójuk és jelenlegi adottságaik alapján a következő alcsoportokra bonthatjuk:

- leszakadt megyeszékhely: Eger,

- a tipikus, korábban háttérbe szorított megyei másodlagos központok: Dunántúl - Mosonmagyaróvár, Pápa, Esztergom, Nagykanizsa; Alföld - Baja, Hódmezővásárhely, Jászberény; Észak-Magyarország - Balassagyarmat,

- a tradicionális, történelmi kis- és középvárosok: Dunántúl - Keszthely, Komárom, Tata, Várpalota ${ }^{3}$; Alföld - Cegléd, Kiskőrös, Kiskunfélegyháza, Csongrád, Szentes, Makó, Szarvas; Észak-Magyarország - Vác, Gyöngyös, 
- és az aktivizálódó, kedvező adottságokkal rendelkező új, döntően 1984 után alapított kisvárosok: Dunántúl - Szentgotthárd, Zalaszentgrót, Csurgó, Fonyód; Alföld - Fehérgyarmat (1978), Mezőhegyes, Gyomaendrőd, Kunszentmiklós; Észak-Magyarország - Szerencs, Tokaj.

A csoporton belüli tagozódás további látványos differenciálódás forrása is, hiszen az elkövetkező években e városok endogén erőforrásai lehetőséget nyújtanak az újabb innovációk fogadására, ezzel funkcióik színesedésére, átalakulására. A megújítás külső tényezőiért ebben a városkörben éles verseny bontakozhat majd ki, ami aztán a megosztását, felbomlását eredményezheti ennek az átmeneti csoportnak.

\section{A leszakadó-átalakulók: szegényes, egyoldalú innovációs környezet}

A leszakadó-átalakulók csoportjába azok a városok tartoznak, ahol ugyan magasak az extenzív tényezők értékei, és az innovációs tényezők közül is több előfordul, ám azok együttes mértéke nem meghatározó. A nehézipar központjai tömörültek ebbe a csoportba, a volt "szocialista városok"; Kazincbarcika, Tiszaújváros, Dunaújváros, Oroszlány, Százhalombatta, Paks, amelyekben kedvezőek az ellátottsági tényezők, de a gazdasági bázis válsága vagy egyoldalúsága következtében nem jelentek meg tömegesen az újdonságok. Ide sorolódott három megyeszékhely is: Miskolc, Szolnok, Szekszárd. Vélhető, hogy innováció fogadási aktivitásuk kedvező szerepkörük vagy felszereltségük ellenére is visszafogottabb, mérsékeltebb. A Budapesttel együtt elvégzett városhálózat elemzésnél a főváros is itt bukkant fel. A főváros egy külön esete, egy sajátos és önálló fejezete az innovációk terjesztésének és megtelepítésének. Betagozódása a leszakadó-átalakuló városok közé ismét jelzi az egyetlen, valóban nagyvárosunk helyzetének, szerkezetének számos ellentmondását ${ }^{4}$.

\section{A passzívak, a mozdulatlanok: innováció-hiányos környezet}

A passzívak, a mozdulatlanok csoportja rendkívül népes a maga 102 városával. Innováció-hordozó elemekre csak elvétve bukkanunk, a városok endogén tényezőinek száma és nagysága is jelentéktelen. A csoportképzés alapját ezeknél a városoknál a hiányos funkciókban, a kis számú innováció-hordozó szervezetben és a szellemi erőforrások mérsékelt voltában kell keresnünk. Döntően a kisvárosok tömörülnek a csoportba, hiszen a 20 ezer fó alatti városok $80 \%$-ánál számításaink szerint az innovációs környezet hiányos. Az innováció-hiányos kisvárosok egyben a perifériák vegetáló centrumai is, hiszen számos megye- és országhatár menti központ található e csoportban. Jellemzőjük még, hogy várossá válásuk alapvetően 1960 és 1984 között zajlott. Végezetül a nyolcvanas évtized (1984-86-89) „városgyártásának” produktumai szinte hiánytalanul felsorakoznak ebben a klaszterben, jelezve azt, hogy a városi rang mennyire elértéktelenedett, ahhoz már nem kapcsolhatók egyértelműen a megújítás tényezői. A centrumszerepet ezek a kisvárosok csak komoly fenntartások mellett testesítik meg, így nem lehetnek az amúgy is depressziós mikrorégiójuk megújításának gócpontjai. 
A csoportban felbukkanó középvárosok közül a többséget a 20 és 30 ezer közötti népességszámú centrumok alkotják. A Dunántúlról itt jelent meg Komló, Dombóvár, Mohács; az Alföldről Hajdúszoboszló, Mezőtúr, Kiskunhalas, Békés, Nagykőrös, Karcag, Törökszentmiklós; Észak-Magyarországról Hatvan; a főváros agglomerációjához szorosan kapcsolódó Gödöllö és Dunakeszi. A nagy-középvárosok (30 és 50 ezer lakos között) közül ötnél - Hajdúböszörmény, Gyula, Orosháza, Ajka és Ózd - hiányos az innovációs környezet. Az alföldi és a dunántúli ipartelepités jelentősebb középcentrumaiban éppen a kialakult gazdasági szerkezet leépülése, az új struktúrák nem, vagy csak nehézkes megjelenése miatt a megújítások terjedése igencsak mérsékelt, pontosabban csak esetlegesen bukkannak fel innovációs elemek. A modernizációs folyamatokat közvetítő tényezők hiánya persze nemcsak az elmúlt évtizedek ipartelepítésére vezethető vissza, hanem a városi funkciók átalakulására, a várossal kapcsolatos igények és elvárások megváltozására is. Talán ezzel magyarázhatjuk, hogy a jelentős múlttal rendelkező nagykun- és hajdúvárosok, de azok egész kisvárosi hálózata is az újdonságok fogadásában leszakadtak, a centrumok látványosan a perifériára szorultak.

\section{Városhálózat jellemzői a kilencvenes évek végén}

Az 1997-1998-as évekre vonatkozó vizsgálatban törekedtünk a kilencvenes évek elejére vonatkozó elemzésben alkalmazott mutatócsoportokat felállítani. Azok tartalma nem mindig egyezett meg az évtized elején fellelhető változókkal, mivel egyrészt már nem voltak előállíthatók, másrészt a tartalmukban újabb elemek, innováció hordozó tényezők jelentek meg, s terjedtek el a városokban. S végül megjelentek további szolgáltatások, intézmények, amik jól képviselték a városi szerepkörök átalakulását, így ezen elemek bevonására is törekedtünk (1. melléklet). Az előző elemzésben alkalmazott változócsoportokat alakítottuk ki, s egy-egy változónál dőlt betüvel jelezzük, hogy melyek ismétlődnek meg az elemzésben, s melyek nem.

Gazdasági-szervezeti aktivitás alatt változatlanul a városok gazdasági potenciálját kívántuk mérni a következőkkel:

- 1000 lakosra jutó müködö jogi személyiséggel rendelkezö vállalkozások száma (db, 1997),

- 1000 lakosra jutó egyéni vállalkozások száma (db, 1997),

- gazdasági szervezetek számának változása (\%, 1992-97 között),

- egy adófizetöre jutó adózás utáni jövedelem_(Ft, 1996),

- 10000 lakosra esö bankfiókok száma (db, 1997),

- nemzetgazdasági beruházások egy lakosra jutó értéke (Ft, 1996),

- munkanélküliek aránya a lakónépességben (\%, 1997),

- munkanélküliek számának változása $(\%, 1993=100 \%, 1997)$,

- iparúzési adó nagysága egy lakosra (ezer Ft, 1997),

- kereskedelmi aktivitás (vásárlóerő) $(\%, 1998)$.

A tevékenység (szolgáltatási) innovációkat a következő mutatókkal mértük:

- személygépkocsik száma 1000 lakosra (db, 1997), 
- bankjegykiadó automaták száma 10000 lakosra (db, 1997),

- Internet szerverek száma 10000 lakosra (db, 1997),

- távbeszélö fövonalak száma 1000 lakosra (db, 1997),

- autó márkakereskedések száma 10000 lakosra (db, 1998),

- utazási irodák száma 1000 lakosra (db, 1998),

- pénzintézetek száma (bankok nélkül) 1000 lakosra (db, 1998),

- biztosítók száma 1000 lakosra (db, 1998),

- ügyvédek száma 1000 lakosra (db, 1998),

- számítástechnikai üzletek száma 1000 lakosra (db, 1998),

- kereskedelmi egységek száma 1000 lakosra (db, 1997).

Látható, hogy ebben a változócsoportban jelentősen tudtuk bővíteni a tényezők számát. Tettük ezt azért, hogy minél erőteljesebben fejezzük ki a városi szerepkörök új elemeit. Ezek a funkciók a városi gazdasághoz, illetve a fogyasztáshoz kötődnek, $\mathrm{s}$ mivel speciális szolgáltatásokat jelenítenek meg a városok térségi, esetenként regionális szerepköreire szintén utalnak, vagy azt számottevően meghatározzák.

Szellemi erőforrásokhoz a következő változásokat rendeltük:

- nappali tagozatos középiskolai tanulók 1000 lakosra (fö, 1997),

- szakmunkástanulók száma 1000 lakosra (db, 1997),

- nappali tagozatos hallgatók száma a felsőoktatási intézményekben (db, 1997).

Centrum funkciók és népesség aktivitás során a következő mutatókat használtuk:

- vándorlási különbözet (ezrelék, 1997),

- a népességszám változása (1990=100, 1990-1997 között),

- természetes szaporulat $(\%, 1997)$,

- lakásállomány változása (1990=100, 1990-1997 között),

- csatornahálózatba bekapcsolt lakások aránya (\%, 1997),

- 1000 lakosra jutó kórházi ágyak száma (db, 1997),

- a központ távolsága vasúton a fövárostól (km, 1997),

- elsőrendủ és másodrendü közutak találkozása a centrumban (db, 1997),

- napi vasúti kapcsolatok száma (Budapesttel és nemzetközi vonatok száma) (db, 1998),

- centrum intézményi állománya ${ }^{5}$ (pontszám összesítés, 1997).

A faktorelemzés alapján a 33 változó kilenc faktorba tömörült, ami a változók 71,7\%-át magyarázza meg. Lényegében öt domináns faktort tudunk elkülöníteni, amelyek összességében 75\%-ban tartalmazzák a városhálózat jellemzőit. A faktorelemzés tehát arra alkalmas, hogy a változók közötti kapcsolatok erősségét és azok homogenitását jellemezze. A faktorok az eloszlásban azonos jellemzőket mutató változókat fogják össze, így egy-egy faktorral, s annak súlyával (a tömörítés arányával) a városhálózatot legjobban meghatározó változó állományt mutathatjuk be. Ugyanakkor azt is megállapíthatjuk, hogy melyek az egymáshoz kapcsolódó, azonos eloszlási jegyek, s ez által a sokaságban megegyezően viselkedő változók, 
mindez aztán elvezeti az elemzőt a hálózat alakítását befolyásoló tényezők és tényezőcsoportok felvázolásához.

Az első faktor tekinthető a gazdasági és fogyasztási potenciálnak, ahol két mutató a vállalkozási aktivitást (jogi személyiségü és egyéni vállalkozások), illetve öt változó pedig a fogyasztási piac jellemzőit fogták át (utazási irodák, kereskedelmi egységek, bankjegy automaták, távbeszélő ellátottság, személygépkocsik). A faktor összességében 22,4\%-ban magyarázza meg a városok összetartozását. Vagyis a kilencvenes évek végére $a$ vállalkozói aktivitáshoz erösen kapcsolódnak a fogyasztást és a szolgáltatást jellemzö tényezők, így a bővülő gazdasági potenciál szükségszerüen magával hozza a városokban a piaci elemek és bizonyos új szolgáltatói tényezők megtelepedését.

A második faktor tekinthető a vonzás erősség faktorának. Ez a változócsomag, amely döntően a centrumok új típusú intézményi ellátottságából (17 új felszereltség mutató) és a kommunikációs potenciálból (Internet szerverek, számítástechnikai üzletek, ügyvédek száma, felsőoktatási hallgatók száma), valamint az elérhetőségből (első és másodrendű közutak száma, napi vasúti kapcsolatok) áll, már 18,6\%-ban magyarázza meg a városhálózat belső kohézióját. A város kedvező elérhetősége szükségszerűen együtt jár az új centrum funkciók nagyobb jelenlétével, ami egyben a kommunikációk szélesebb tereit is megnyitják, azaz jelentősen növelik a városok vonzását, szerepeinek nagyobb térségben (régióban) való érvényesülését.

A harmadik faktort a humánerőforrások alkotják (szakmunkástanulók, középiskolások, vándorlási különbözet, kórházi ellátottság) 12,5\%-ban, amely jelzi, hogy változatlanul fontos tényező a humáneröforrások jelenléte, azzal való ellátottság, illetve bizonyos intézményi elemeinek megléte.

A negyedik faktorban a jövedelmi pozíciót jelző tényezők sűrüsödtek, s meghatározó súlyt képviselnek a városhálózat jellemzésében (10,8\%). Az iparüzési adó, a gazdasági egységek beruházása és az adózás előtti jövedelem nagysága, továbbá a vásárlóerő indexe, együttesen a centrum fogyasztási potenciálját képviselik. Azonos nagysággal (10,6\%) szerepel a faktorok között ötödikként, a fővárostól való távolság és a munkanélküliek aránya. A mutatóknak az összetartozása természetes, így nevezhetjük a periféria faktorának.

A kilencvenes évek utolsó harmadában tehát a városhálózat összetartozását, s egyben fejlődését nem a hagyományos gazdasági tényezőkre, vagy éppen a tradicionális, intézményi centrum funkciókra vezethetjük vissza, mint az évtized elején. Ezeknek a változóknak egy-egy eleme természetesen még hat, de már a rendező elvekben kimutathatók a változások, az elmozdulások a szerkezetben felismerhetők.

A hálózat összetartozását tehát már nem az infrastrukturális ellátottsági mutatók, valamint a centrumok tradicionális intézményi ellátottsága formálja, hanem látványosan megjelennek az üzleti és gazdasági szolgáltatást jellemző tényezők, illetve a gazdasági potenciált képviselő elemek. Elötérbe kerül és szoros kapcsolatban áll az új szolgáltatásokkal a centrumok elérhetösége és kommunikációs felszereltsége is. Mindez jelzi, hogy magának a centrumnak külső kapcsolata, illetve közlekedési helyzete felértékelődik, ami szorosan kötődik az új információs technikák jelenlét- 
éhez is. Felismerhetö továbbá, hogy a humáneröforrások és a jövedelmi potenciál szintén formálja a hálózatot, befolyásuk már az elöző tényezőkkel megegyező nagyságrendü. Szoros az összetartozás a lakossági fogyasztási potenciál és a gazdaság beruházási aktivitása között, s mindezek aztán hatnak a szolgáltatások piacára, azok egységeinek megjelenésére is.

A népesség számának változása, vagy a város növekedését jelző lakásállomány, azaz a hálózat mennyiségi elmozdulását jelző paraméterek, elemzésükben nem mutattak határozott kapcsolatot, a megújítást hordozó elemekkel, azoktól elkülönültek. Mindez jelzi, hogy a városi gazdaság által gerjesztett piac, s annak minél szélesebb kínálatát nyújtó intézményei válnak a kilencvenes évek utolsó harmadában a városhálózat formálásának tényezőjévé. Nem lehetett a lakásállomány növekedése jelentős hatással a hálózatra, mert még nem indultak meg a háztartások beruházásai, azok egyenletesen alacsony szinten voltak a városokban, így inkább a szintén mérsékelt népességi tényezőkhöz kapcsolódtak.

Az elmozdulás megtörtént tehát a városhálózatban, ennek véleményünk szerint még az első stádiumában vagyunk, a mennyiségi elmozdulás szakaszában. Azok a városok lettek tehát nyertesei a kilencvenes éveknek, ahol a gazdasági potenciálon (aminek tartalma további elemzéseket kíván meg $^{6}$ ), vagy éppen a korábbi regionális funkciók bázisán ki tudtak épülni a modern üzleti és gazdasági szolgáltatások intézményei. Kedvező elérhetőséggel rendelkeznek, a humánerőforrásai számottevőek és annak széles, szinte teljes vertikumát fogják át, egyben a jövedelmi - s ezzel együtt a fogyasztási - potenciáljuk magas. Azonban jeleznünk kell, hogy azok a városok, ahol a lakosság jövedelmi helyzetében határozott az elmozdulás, illetve ennek következtében a fogyasztási aktivitás erőteljesebbé válik, ott a háztartások nagyberuházásai (lakásépítés, lakáspiac) is megkezdődnek, így a szerkezet további megoszlása, vagy pontosabban átrendeződése várható.

\section{A városhálózat tagozódása a kilencvenes évtized utolsó harmadában}

A városhálózat összetartozását képviselő tényezők meghatározása után vizsgáljuk meg, hogy a városokhoz rendelt faktor értékek milyen csoportokat szerveztek össze, azaz a hálózat egyes tagjai ebben a faktorok által meghatározott térben miként különülnek el. A csoportok elnevezésében törekedtünk a kilencvenes évek elején végzett vizsgálatban megadott fogalmakra és lehetőség szerint a tartalomra analógiákat adni, hogy az összevetés egyszerübb, vagy inkább látványosabb legyen.

\section{Aktív és stabil városok: az innovációk és a gazdasági megújitás központjai}

A csoportra az jellemző, hogy mindegyik változó érték magas, többségében eléri, sőt meghaladja az országos átlagot. Érvényes ez az üzleti szolgáltatásokra, a gazdasági-szervezeti aktivitásra, de a humánerőforrások és a fogyasztási potenciál jellemzőire is. A megyeszékhelyek közül 16 található itt (kivétel Tatabánya és Szolnok), továbbá a két nagyváros (Sopron, Hódmezővásárhely), a tradicionális, mezoregionális funkciót (oktatás, szolgáltatás) ellátó (Baja, Szarvas, Keszthely, Gyöngyös), 
valamint a határ menti (Mosonmagyaróvár) középváros, illetve az agglomerációs középváros (Gödöllő), és egy feltörekvő, gyors megújítást formáló kisváros (Rétság).

\section{A speciális szerepkörrel rendelkezö városok: üdülö- és iparvárosok}

Az elemzések során elkülönül két városcsoport. Az első az üdülővárosok, többségében a Balaton mellett, illetve a néhány termál- és gyógyturizmusból élő gazdag, jól felszerelt kisváros (Hévíz, Zalakaros). Ezeknek a városoknak az infrastrukturális ellátottsága, személyi és üzleti szolgáltatást nyújtó intézményei, de a jövedelmi, fogyasztási potenciáljuk is kiemelkedik a hálózatból.

A másik alcsoportba öt város (Martfü, Paks, Százhalombatta, Szentgotthárd, Tiszaújváros) tartozik. Az ”egy gazdasági szervezet egy város” modelljei ezek, mérsékelt szolgáltatási szinttel, de igencsak magas szintủ infrastruktúrával és fogyasztási-jövedelmi nívóval rendelkező centrumok.

III. Az átalakuló, helyzetüket javitani képes városok: gazdasági és társadalmi szerkezetükben stabilizálódó és városi-térségi szerepüket szélesitő centrumok

A vegyes csoport nagy különbségeket mutat, azonban már jelzi az elmozdulást, az új városi funkciók megtelepedését, s ezzel a hálózat határozott második, kistérségi, vagy éppen mezoregionális centrumainak kialakulását. A klaszterre jellemző, hogy a szolgáltatási potenciál néhány tényezőben megközelíti az országos átlagot, humánerőforrásokból jól ellátottak, a gazdaságuk teljesítőképessége átlagos, viszonylag közel vannak Budapesthez, a vándorlási különbözetük mérsékelt, az új centrum funkciók szervezetei megtelepedtek. Többségében ebben a csoportban találhatók az 1990 elötti ipari központok (Ajka, Dorog, Dunaújváros, Oroszlány, Pápa, Szolnok, Tatabánya, Várpalota, Vác), ahol a szerkezeti váltás az évtized elején kisebbnagyobb aktivitással elkezdődött, mostanára folytatódik, de több esetben a kimenet iránya még nem egyértelmü. Nagy számban vannak a klaszterben az 1971-1989 között alapított kis- és - ma már - kisközépvárosok (22 város), de néhány tradicionális középváros is ide sorolódott (Pápa, Komárom, Kalocsa, Kiskunfélegyháza, Gödöllő, Nagykörös, Vác, Hatvan).

Ebben a városkörben tehát számos középfokú szerepkör már korábban kiépült, ami aztán vonzza az új üzleti és gazdasági szolgáltatásokat, azok intézményeit, ám több esetben a gazdasági szerkezet csak lassan stabilizálódik, a jövedelmi és a fogyasztási potenciálok mérsékeltek, viszont a térbeli helyzetük miatt, vagy éppen adottságaik következtében kedvező irányban mozdulhatnak el.

IV. A köztes, átmeneti helyzetü városok: periférikus helyzetben, illetve a Budapest agglomerációjában található centrumok, instabil szerkezettel

Nagy súllyal találhatók a csoportban az 1989-1998 között alapított új kisvárosok (26 város). Gyenge gazdasági potenciál, a humánerőforrás állomány jóval a városi átlag alatt van, távol találhatók a nagyvárosoktól, kivétel a budapesti agglomeráció 
kisvárosai, közlekedési kapcsolataik kedvezőtlenek, viszont már megjelentek az üzleti szolgáltatások egyes elemei, így bizonyos kistérségi funkciók miatt fogyasztási központnak tekinthetők, de alacsony színvonalú az infrastrukturális ellátottságuk. Néhány tradicionális kisközépváros ide sorolódott (Jászberény, Kőszeg, Makó, Szentendre). A Budapest környéki agglomeráció városainak többsége ebbe a csoportba került, hiszen ezekben a városokban még alacsony szintűek a szolgáltatások, viszont látványosan rendeződik át a gazdaság, vagy gyors az infrastruktúra kiépülése, illetve megkezdődött a népesség betelepülése. A Duna-Tisza köze kisvárosai szintén instabil szerkezetüek, hiszen a nagy és középvárosokban koncentrálódik a fogyasztás, itt jelennek meg a szolgáltatások, így az újonnan alakult kisvárosok mérsékelt, visszafogott városi funkcióval rendelkeznek.

\section{A leszakadók: a funkciókban hiányos városok}

A csoport mutatja a legkedvezőtlenebb ellátottsági és felszereltségi állapotot a hazai városhálózatban. Az állomány összetételében a fiatal, az 1989-1998 között alapított városok további tagjai (18 egység) csoportosulnak, de találunk itt tradicionális középvárost (Nagykanizsa, Gyula), vagy kisközépvárost (Túrkeve, Sátoraljaújhely, Hajdúszoboszló), sőt vannak problémával küzdő ipari, szolgáltatói centrumok (Komló, Ózd, Záhony, Kazincbarcika, Sajószentpéter). Alacsony a szolgáltatói potenciál, az új funkciók fogadása mérsékelt, a humánerőforrások gyengék, magas a munkanélküliség, a jövedelemtermelő képesség jelentősen az országos átlag alatt található, a legtávolabb vannak a városok átlagában Budapesttől, az elérhetőségük a legrosszabb a csoportok között, térségi és a helyi fogyasztási potenciál szintén kedvezőtlen.

Azt lehet mondani, hogy a városok többsége a Tiszántúlon és ÉszakMagyarországon található, de érdekes, hogy a nyugati határhoz közeli Csorna és Fertőd is idesorolódott, vagy Baranya megye tradicionális kisvárosai is itt jelennek meg. Összességében a Tiszántúl és Észak-Magyarország kisvárosai a leszakadók kategóriájában találhatók. A hálózat ezen elemei tehát képesek befogadni, megtelepíteni az új szolgáltatásokat, azokat részben a közeli nagyvárosok látják el, vagy a nagyobb gazdasági potenciállal rendelkező tradicionális középvárosok. Az agrártérség új, vagy éppen tradicionális (hajdú városok, nagykun középvárosok) átállása a piacgazdaság intézményeire késik, a szerkezetük tradicionálisabb, hiszen a nagyközpontok ebben a periférikus térben erős szívást gyakorolnak az új szolgáltatásokra és fogyasztási elemekre.

\section{Elmozdulás a városhálózatban}

Van-e elmozdulás a városhálózatban? Erre a kérdésre pontos, s tudományosan megalapozott választ csak akkor tudunk adni, ha azonos paraméterekkel mérjük két időpontban a struktúrát. Ezt a korábban is jelzett okok miatt nem tudtuk megtenni, így egy provizórikus összehasonlítást végzünk a két időpontban kidolgozott elemzés között. 
Az első megállapítás, hogy a hálózat jellemzői között a modern üzleti és gazdasági szolgáltatást képviselö tényezőknek és intézményeknek határozottabb az összetartozása, egymásra épülése. Ezek az új városi funkciók egymáshoz kapcsolódnak, lényegében a gazdasági potenciál által motivált fogyasztási teljesítmények következtében egyre nagyobb számban és bővülő minőségben jelennek meg a városokban. Az évtized végére már nőtt a tömegszerüségük, mind kínálatban, mind térbeli terjedésben, így domináns elemei lettek a hálózat jellemzésének.

A második megállapítás, hogy míg a kilencvenes évek elején a tradicionális centrum funkciók, azaz többségében a közszolgáltatáshoz kötődő intézmények (oktatás, egészségügy, kultúra, igazságügy, közigazgatás) jelenléte és a gazdasági tényezők voltak a városhálózatot alapvetően és a tagozódását befolyásoló jellemzők, addig a kilencvenes évek végére már az üzleti és gazdasági szolgáltatások, mint piaci viszonyok kerültek elötérbe. Visszaszorultak tehát a közszolgáltatásokra épülő hálózatot alakító tényezők, s helyükbe léptek a gazdasághoz, vagy a városokhoz, mint piaci és fogyasztási, egyben népességkoncentráció és vonzási funkcióikhoz kötődő tevékenységek.

A harmadik sajátosság, hogy a piaci-fogyasztási tényezők mellett, azokkal igen csak szoros kapcsolatban felértékelödött a városok elérhetősége, megközelithetősége. Ez szinte logikus következménye az előzőknek, hiszen minél jobb a város elérhetősége, annál határozottabb a vonzása a térségére, s ezzel együtt széles bázisát fogadja be a szolgáltatásoknak, egyre gazdagabbá válik a fogyasztási piacának kínálata.

A hálózat tagozódásának változása (1. táblázat) látványos, hiszen az 1990-ben megfigyelt 164 város 59\%-a (97 egység) mutatott valamiféle elmozdulást. Növekedett a stabil és aktív városok száma, amelyek lényegében a megyeszékhelyek, nagyvárosok, illetve néhány tradícióval rendelkező középváros. Ezek a centrumok a hálózat biztos pontjai, regionális szerepköröket alakítottak ki, s a vizsgálatunk szerint a városi népesség 35,2\%-át fogják át.

Átrendeződött a speciális funkciókkal rendelkező városok csoportja. Már nem a vegyes funkciók, hanem a koncentrált egyedi, kiemelkedő lokális sajátosságok következtében különülnek el városok, amelyek ugyan több tényező miatt kedvező pozíciót alkotnak. A tartós fejlődésük viszont kitett a konjunkturális hatásoknak, vagy éppen a szezonalitásnak, így fejlesztési stratégiáikban a térségi fogyasztási és szolgáltatási szerepkörök bővítése kívánatos. Az átalakuló, helyzetüket javítani képes városok csoportjában nagy átrendeződés zajlott az elmúlt években. A kilencvenes évek közepén már sejtettük, hogy a hálózat ezen elemei még bizonytalan helyzetben vannak, lesznek. Nos, több nagyvárosnak sikerült elhagyni ezt az instabil kategóriát (Hódmezővásárhely, Eger, Szekszárd), hasonlóan több tradicionális középváros rendezte, stabilizálta helyzetét (Baja, Keszthely, Mosonmagyaróvár). 


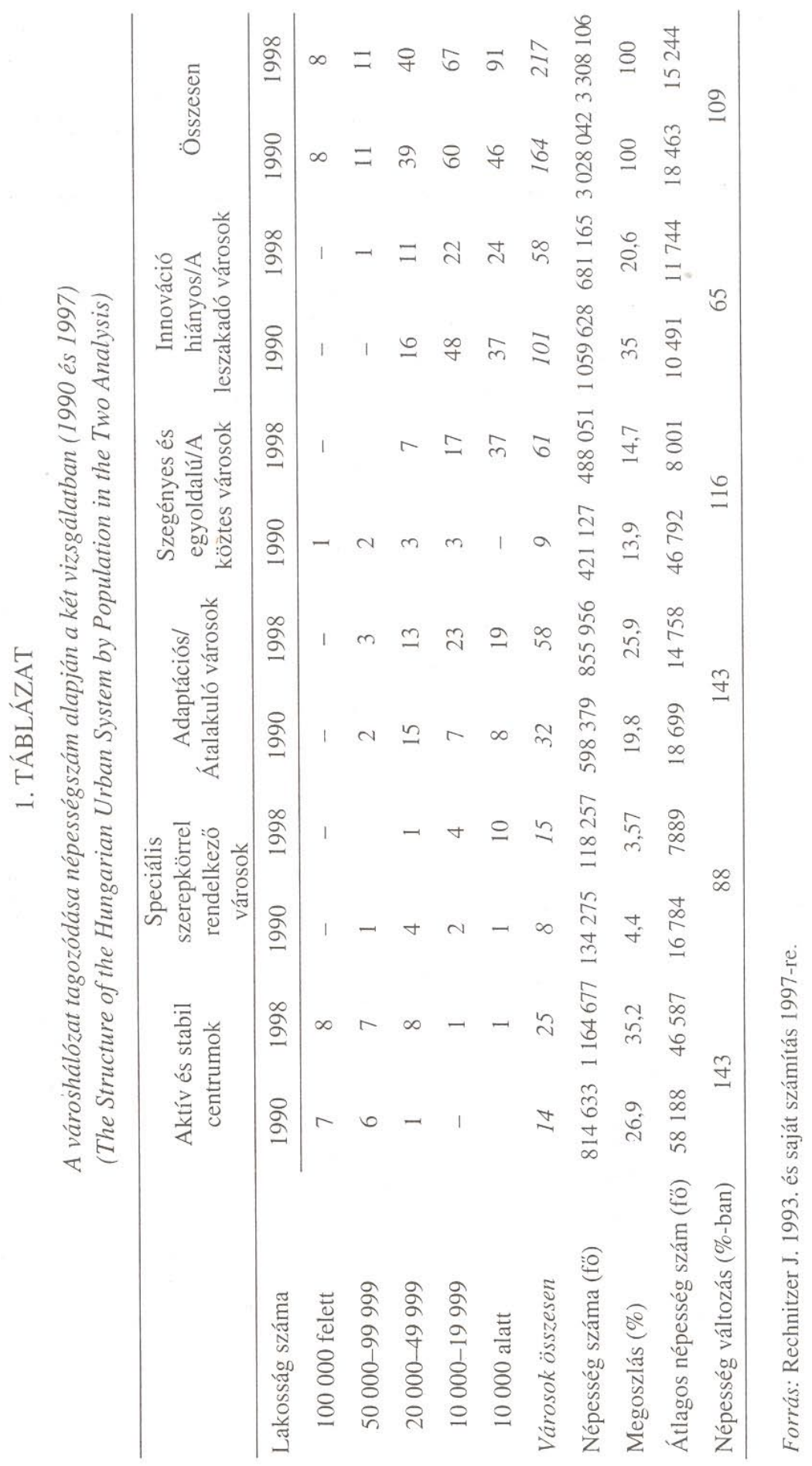


A tömegesen „benyomultak” az átalakuló, a helyzetüket javítani képes, de egyben a városhálózat harmadik ${ }^{7}$ stabilizációs szintjét képviselő kategóriában, az 19711988 között alapított kis- és kisközépvárosok. A kilencvenes évek elején ezeknek a városoknak a többségét innováció hiányos, erősen leszakadó centrumnak tekintettük, de az évtized utolsó harmadára már helyzetbe hozták magukat. Határozottabb az elmozdulás a Békéscsaba-Salgótarján vonaltól nyugatra lévő térségek városaiban, míg ettől a vonaltól keletre csak egy-két város, többségében az említett szabolcsi centrumok zárkóztak fel.

A hetvenes-nyolcvanas években alapított kis- és középvárosok tehát nagyobb számban voltak képesek helyzetüket javítani, fogadni az új szolgáltatási intézményeket, s egyben alakítani térségi pozícióikat. Vélhetően a kilencvenes évek elejére kialakult ezeknek a városoknak az intézményrendszere, vonzáskörzete, s ez is hozzájárult a további új funkciók megjelenéséhez, megtelepedéséhez.

Szétesett az első vizsgálat negyedik, a szegényes és egyoldalú innovációt megjelenítő volt szocialista és iparvárosok csoportja. Egy részük az új iparváros klaszterbe ment át (Paks, Százhalombatta, Tiszaújváros), másik részük rendezte sorait, talán a megyeszékhely jellege miatt (Szekszárd, Miskolc), s csak egyedül Szolnok lépett kisebbet, hiszen az átalakuló, városok csoportjába sorolódott.

Az innováció hiányos városok klasztere szétbomlott a kilencvenes évtizedben. Ebből egy jelentős város tömeg (1971-1988 között alapítottak) került az átalakuló, stabilizálodó városok csoportjába. Létrejött, tehát az a városkör, amely leküzdötte a rendszerváltozás megrázkódtatásait, a városi funkcióiban egyre nagyobb szerepet kapnak a piaci tényezők, s a megújítás elemei. Változatlanul találunk mozdulatlan városokat, többségében a Tiszántúlon és Észak-Magyarországon, így a békési, a hajdú, a nagykun, valamint az abaúj, s a zempléni kisvárosokban nem érzékelhető, hogy nagyobb teret kapott volna a modernizáció. Megjelentek ugyan az új intézmények, a piacgazdaság elemei, az új szolgáltatások egységei, de azoknak a súlya a városállomány egészéhez képest még mindig alacsony, visszafogott. Érdekes, hogy a Dunántúlon csupán négy mozdulatlan kisvárost találunk ebben az összefüggésben (Csorna, Szigetvár, Mohács, Tolna).

A kilencvenes évek csinált kisvárosait (53 egység) nem lehet egyszerüen besorolni a leszakadók kategóriájába, sőt ezek a centrumok kimondottan megosztottak, más és más jellemzőket fognak át. Az új üdülővárosok mellett egy iparváros, sőt négy egység az átalakuló kategóriába került (Csepreg, Aszód, Pécsvárad, Máriapócs). Köztes átmeneti helyzetben van 26 város, többségében a Dunántúlon, a fóvárosi agglomerációban, a Duna-Tisza közében, s a leszakadók változatlanul a Tiszántúlon. A kilencvenes években városi rangot kapott települések többsége tehát számottevően nem járult hozzá az egész hálózat modernizációjának emeléséhez, sőt annak színvonalát lényegében rontotta. Ez a nem kellően átgondolt várossá nyilvánítás csak fokozta a hálózaton belüli feszültségeket. A várossá válás kritériumai az intézményi infrastruktúrához, a mennyiségi jellemzőkhöz kötődnek, nem pedig a modernizációs elemek jelenlétéhez, azok térbeli hatásainak ösztönzéséhez (CsapóKocsis 1997; Kara 1998). 
Az elemzések során a közlekedési kapcsolatoknak jelentős szerepe volt a hálózat egyes elemei modernizációjában. Nos, ha összevetjük az autópálya hálózat elérhetőségét különböző idősávokban és a városok tagozódását, egy sajátos szerkezetet látunk. Nem egyértelmủ és közvetlen a kapcsolat, a két összefüggés között. Többségben vannak az átalakuló és a köztes városok a legkedvezőbb, a 30 percen belüli elérhetőségi sávban. Vélhető, hogy a jövőben ez lesz az a városkör, ahol a szerkezeti változások felgyorsulnak, nagyobb intenzitással jelennek meg a piaci szolgáltatások és azok intézményei, s vonzóbbak lesznek nemcsak a gazdasági egységek, de a népesség számára is.

\section{Összefoglalás, a jövő trendjei}

A hazai városhálózatban a kilencvenes években erőteljes átrendeződés regisztrálható. Látványosan terjedtek a piacgazdaság intézményei, amelyek a kilencvenes évek végére meghatározó tényezői lettek a hálózat egésze alakításának. Ezekre a tényezőkre nagyobb népességgel, számottevő vonzáskörzettel, kiforrott, több szintü intézményrendszerrel és jövedelemtermelő képességgel rendelkező nagyvárosok gyorsabban reagáltak, így helyzetüket stabilizálni tudták, de egyben térségi szervező szerepköreiket is szélesítették.

Elkülönülnek a hálózatban egy-egy funkcióra, vagy egy-egy domináns gazdasági (ipari) tevékenységre épülő városok. A tradicionális középvárosok és a hetvenesnyolcvanas években alapított kis- és kisközépvárosok fokozatosan leküzdötték a rendszerváltozás negatív gazdasági hatásait. Így befogadták a piacgazdaság intézményeit, teret kaptak a szolgáltató szektor modernizációt közvetítő intézményei is.

A köztes, erősen változó, még nem kellően stabil szerkezettel és intézményrendszerrel bíró városállományban - ahol a csinált városok szép számban jelen vannak még csak esetleges a megújítást hordozó intézményrendszer kiépülése, a gazdasági szerkezet bizonytalan, a jövedelmi pozíciók mérsékeltek, így a jövőbeli elmozdulásuk bizonytalan. Felrajzolható, ismételten nagyobb számban a kilencvenes években alapított, illetve a Tiszántúl elmúlt 20-30 évben létesített centrumaiból a leszakadók csoportja. Történtek elmozdulások a piaci intézmények és szolgáltatások, s a gazdasági bázis fejlesztésében, azonban ennek üteme elmaradt a hálózat egészének átrendeződésétől, így a lemaradásuk látványos, kitapintható. Ennek a városkörnek a többsége agrártérségben, vagy ipari válságtérségben található, így nem képesek sem energiát felszívni, sem pedig kibocsátani a térségüknek.

A városhálózat tehát a kilencvenes években nem volt mozdulatlan, a rendszer egésze és annak egyes tagjainak többsége megkísérelt alkalmazkodni a piacgazdasághoz, részben az intézmények befogadásával, részben pedig az új térségi szerepkörök szélesítésével. A hálózat többsége leküzdötte a kilencvenes évek elejére jellemző dermedtséget. A kis- és középvárosok egyre nagyobb csoportjai az ország szinte mindegyik régiójában vagy visszarendezték funkcióikat, vagy éppen felkészültek az új szerepek fogadására. Elkezdődött a hálózat felhígulása a kilencvenes években, ami növelte bizonyos régiókban a várossürüséget, s ezzel a versenyt az új 
szerepkörökért, míg másutt viszont a régiók elmaradottsága következtében az új városok valójában nem tudtak a közvetítői lenni a modernizáció intézményrendszereinek. A hálózat egyértelmủ nyertesei a sikeres városok - ugyan eltérő ütemben és időben - a nagyvárosok lettek, ahol kialakult és stabilizálódott a piacgazdaság új intézményrendszere, s ezzel térségi hatásuk új, alapvetően a fogyasztásra építő dimenziót kapott.

A városhálózat jövőbeli alakulásának a kilencvenes évek alapján elörevetíthető trendje a nagyvárosok további erősödése, azok funkcióinak szélesedése, ezáltal egymás közötti versenyének kiéleződése. A tradicionális középvárosok és a nyolcvanas évek közepéig alapított kisvárosok helyzetének stabilizálódása várható, és kistérségi, jobb esetben mezoregionális szerepköreik bővülése. A speciális helyzetü városok körének bővülésével kell számolni, így az üdülő, agglomerációs (regionális központok mellett is) és új - már érzékelhető - jelenségként a határ menti városoknál. S végül a kisvárosok élénkülése azokban a régiókban lehet számottevő, ahol a tartós gazdasági növekedés feltételei biztosítottak, s ezáltal be tudnak kapcsolódni a nagyvárosok gazdasága által egyre határozottabban formált regionális hálózatokba. Ahol a nagyváros nem képes a hálózat formálását erősíteni, még saját szerkezetének átrendezésével és stabilizálásával lesz elfoglalva, azokban a régiókban a kisvárosok tovább stagnálnak, az intézményeik és szolgáltatásaik csendes leépülése mellett. Vélhetően a további városalapításra, mint egy közigazgatási és politikai gesztusra szükség lesz a jövőben is. Vannak még városhiányos terek az országban, azonban ezek az újabb egységek csak kistérségeik vonatkozásban fognak hatni, vagy éppen hatnak jelenleg is, döntően nem befolyásolják a hálózat egészének fejlődését. A verseny és az európai hálózatba való minél teljesebb betagozódás a nagyvárosokra lesz jellemző, ezek az egységek lesznek a hálózat formálói, s egyben a regionális szintű struktúrák alakítói a jövőben.

\section{Jegyzetek}

${ }^{1}$ Ennél a mutatónál sajnos éppen a népszámlálási adatok hiánya miatt csak az 1980. évi értékkel dolgozhattunk.

${ }^{2}$ Az intézményi ellátottságot 12 tényező demonstrálta: a helyi autóbusz közlekedés viszonylatainak a száma, a gázfogyasztók száma, a zöldterület nagysága, a kórházi ágyak, a középiskolai osztálytermek, a müvelődési intézmények, a kereskedelmi és vendéglátóhelyek száma, a kereskedelmi szálláshelyeken a szobák száma, az elvezetett szennyvíz mennyisége, az egészségügyi általános körzetek száma, a városban lévő felsőfokú tanintézetek száma és a pénzintézetek száma. Ezen mutatók értékeit pontozásos rendszerrel sủrítettük egy változóba. A számításokat néhai Sas Béla végezte.

${ }^{3}$ A volt, ún. szocialista városok közül csak Várpalota jelent meg ebben a csoportban. Vélhető, hogy a városban erőteljesebb megújítási, átalakítási folyamatok indultak meg, felzárkózása már érzékelhető, kimutatható.

${ }^{4}$ A fővárosnak az innovációk terjedésére gyakorolt hatása meghatározó, azonban nem lehet, éppen eltérő jellege és ebből adódóan dimenziói miatt a városhálózat többi elemével együtt vizsgálni.

5 A következő intézményeket vettük figyelembe a centrum funkcióknál: városi bíróság (5), városi ügyészség (5), munkaügyi központ kirendeltsége (3), adóhivatal kirendeltsége (3), vállalkozásfejlesztési iroda (3), helyi televízió stúdió (3), kábeltelevízió hálózat (2), helyi rádió (3), helyben kiadott folyóirat (5), hírlap és könyvkiadó (5), könyvkiadók, könyvterjesztök (3), ipari park (5), múzeumok és kiállítóhelyek száma (10 felett 5 pont, 5-9 egység 4 pont, 1-4 egység 3 pont), állandó színházi társulat 
(5), országos mozgalmakban való részvétel („Virágos Magyarország”, „Egészséges Város”) (2), Internetes honlap (1).

${ }^{6}$ A csoportelemzések mutatnak majd rá arra, hogy a legtöbb sikeres város olyan nagyváros, ahol lényeges gazdasági potenciál nem áll rendelkezésre, hiszen döntően közszolgáltató intézményeket tömörítenek, amelyek a jövedelmek újraelosztásából és nem pedig a jövedelemtermelésből élnek. Vélhetöen a nagyközpontokban jelentős illegális jövedelmek is termelődnek, melyek szintén eröteljesen hatnak a szolgáltatói bázis szélesítésére, illetve a fogyasztási potenciál növelésére.

${ }^{7}$ Az első szint a fóváros, a második a regionális központok, a harmadik a mezoközpontok, a negyedik a kistérségi centrumok.

\section{Irodalom}

Rechnitzer J. (1993) Szétszakadás vagy felzárkózás. A térszerkezetet alakitó innovációk. MTA RKK, Györ.

Csapó T.-Kocsis Zs. (1997) A várossá nyilvánítás elvi kérdései és a potenciális városok az ÉszakDunántúlon. - Tér és Társadalom. 1. 183-197. o.

Kara P. (1998) Várossá válások az önkormányzati rendszerben. - Gazdaság és Gazdálkodás. Április. 265-267. o.

Melléklet

A vizsgálathoz alkalmazott változók

(Indicators Applied for the Analysis)

Kód A változó megnevezése Évszám Forrás

CAKT0 A település vándorlási különbözete 1997-ben (ezrelék)

CAKT1 A település népességszámának változása 1990 és 1997 között $(1990=100)$

CAKT2 A település természetes szaporulata 1997-ben (ezrelék)

CAKT3 A település lakásállományának változása 1990 és 1997 között $(1990=100)$

CAKT4 A csatornahálózatba bekapcsolt lakások aránya 1997-ben (\%)

CAKT5 Az 1000 lakosra jutó kórházi ágyak száma 1997-ben (db)

CAKT6 A település távolsága a fővárostól vasúton $(\mathrm{km})$

$1997 \quad$ KSH

1990-1997 KSH

$1997 \quad$ KSH

1990-1997 KSH

$1997 \quad$ KSH

$1997 \quad$ KSH

1997 MÁV menet-

rend

CAKT7 A településen áthaladó elsőrendủ és másodrendű föutak száma $(\mathrm{db})$

1997 Magyarország autóatla-

sza

1998 MÁV menetrend ban $(\mathrm{db})$

CAKT9 A település centrum jellegére vonatkozó mutató 17 változó alapján számítva, 1997-ben

G2 Az 1000 lakosra jutó müködő jogi személyiségü vállalkozások száma 1997-ben (db)

G3 Az 1000 lakosra jutó regisztrált egyéni vállalkozások száma 1997-ben (db)

G4 A bejegyzett gazdasági szervezetek számának változása 1992 és 1997 között $(1992=100)$

1997 Saját számítás

$1997 \quad \mathrm{KSH}$

$1997 \quad \mathrm{KSH}$ 
G6

Az 1 lakosra jutó adózás előtti jövedelem 1996-ban (ezer Ft)

G7 A 10000 lakosra jutó bankfiókok száma a településen 1997-ben (darab)

G8

A megvalósult beruházások 1 lakosra jutó értéke 1996-ban (ezer Ft)

G9 A munkanélküliek aránya a teljes népességhez viszonyítva 1997-ben (\%)

G10 A településen élő munkanélküliek számának változá- 1993-1997 sa 1993 és 1997 között $(1993=100)$

G11 Az 1 lakosra eső iparúzési adó nagysága 1997-ban (ezer Ft)

G12 A településre jellemző vásárlóerő index 1998-ban (országos átlag $=100$ )

SZERO1 A nappali tagozatos középiskolai tanulók száma 1000 lakosra vetítve 1997-ben (fö)

SZERO2 A szakmunkástanulók száma 1000 lakosra vetítve 1997-ben (fö)

SZERO3 A felsőfokú oktatási intézményekben tanulók száma 1000 lakosra vetítve 1997-ben (fö)

SZT1 Az 1000 lakosra jutó személygépkocsik száma 1997ben $(\mathrm{db})$

SZT2 Az 1000 lakosra jutó távbeszélő fővonalak száma 1997-ben (db)

SZT3 A 10000 lakosra jutó autó márkakereskedések száma 1998-ban (db)

SZT4 Az 1000 lakosra jutó utazási irodák száma 1998-ban (db)

SZT5 Az 1000 lakosra jutó pénzintézetek száma 1998-ban (db)

SZT6 Az 1000 lakosra jutó biztosítótársaságok száma 1998-ban (db)

SZT7 Az 1000 lakosra jutó ügyvédek száma 1998-ban (fö)

SZT8 Az 1000 lakosra jutó számítástechnikai üzletek száma 1998-ban (db)

SZT9 Az 1000 lakosra jutó kereskedelmi egységek száma 1997-ben (db)

SZT10 A 10000 lakosra jutó bankjegykiadó automaták száma 1997-ben (db)

SZT11 A 10000 lakosra jutó Internet szerverek száma 1997ben $(\mathrm{db})$
1996

$\mathrm{KSH}$

1997

1996

Pénzügyi

és Tözsdei

Almanach

$\mathrm{KSH}$

KSH

$\mathrm{KSH}$

1997

$\mathrm{KSH}$

1998

Gfk Hungary

1997

$\mathrm{KSH}$

1997

$\mathrm{KSH}$

1997

$\mathrm{KSH}$

1997

KSH

1997

$\mathrm{KSH}$

1998

1998

Saját gyüjtés

Idegenfor-

galmi Almanach

1998 Tőzsdei

Almanach

1998 Tözsdei

Almanach

1998 Jogásznapló

1998. Magyar

Jogász Egylet

Bp.

1998

Yellow

Pages, Matáv

telefonkönyv

$\mathrm{KSH}$

1997 Saját gyüjtés

1997 Internet 
